\title{
ALBANSKI ZLATARI I PEKARI S KOSOVA U ZAGREBU: MIGRACIJE I ETNIČKO PODUZETNIŠTVO
}

\section{MARIJETA RAJKOVIĆ IVETA}

Filozofski fakultet Sveučilišta u Zagrebu

Odsjek za etnologiju i kulturnu antropologiju

Ivana Lučića 3, Zagreb

mrajkovi@ffzg.hr

iD orcid.org/0000-0002-4988-1828

\section{RINA GECI}

Kosovo, 10000 Priština, Johan Gëte 19

rinageci@gmail.com

iD orcid.org/0000-0001-7556-1492
DOI:10.17234/SEC.29.10

Izvorni znanstveni rad

Primljeno: 7. 5. 2017.

Prihvaćeno: 24. 7. 2017.

Ovaj rad nalazi se u otvorenom pristupu i može se distribuirati u skladu s odredbama licencije CC BY-NC-ND 4.0 HR

Rad je temeljen na kvalitativnim intervjuima s Albancima iz Kosova, zlatarima (katolicima iz Prizrena) i pekarima (muslimanima iz regije Hasi) koji žive u Zagrebu. Kazivači su ekonomski migranti i njihovi potomci koji su tijekom suživota u Jugoslaviji na prostor Republike Hrvatske dolazili raditi, posebice u turistička mjesta na jadranskoj obali. Većina ovih sezonskih migracija pretvarana je u trajna preseljenja u grad Zagreb, a raspadom Jugoslavije, ovi su migranti postali pripadnici nacionalne manjine u Republici Hrvatskoj. Koristeći etnografiju pojedinačnoga, na osnovi teorija migracijskih sustava, teorija o društvenoj i kulturnoj integraciji te transnacionalnoj teoriji cilj je rada bio istražiti njihova življena migrantska iskustava. $U$ radu se prikazuju uzroci migracija i remigracija, razlozi i intenzitet (ne)pretvaranja sezonskih u trajne migracije, učenje zanata i etničko poduzetništvo. Istražujući njihov život u Zagrebu, zanimala nas je njihova svakodnevica, odakle biraju bračnog druga, kojim jezikom govore, na koje su načine povezani s mjestom podrijetla, participiraju li u migrantskim društvima te kako provode slobodno vrijeme.

Ključne riječi: Albanci s Kosova, Zagreb, pekari, zlatari, sezonske migracije, nacionalna manjina

\section{UVOD}

Šetajući centrom Zagreba, nailazimo na brojne zlatarnice. Prezimena njihovih vlasnika često su tipična albanska prezimena. Također, prema nazivima radnji, primjerice zambak (albanska riječ za ljiljan, jedan od simbola grada Prizrena iz kojeg je većina albanskih zlatara i filigranista 
doselila u Zagreb), lako je prepoznati da su vlasnici Albanci. Dalje od centra, raspršene po gradu, pekarnice često nose ime sela iz kosovske regije Hasi ${ }^{1}$ odakle su podrijetlom vlasnici Albanci. Četrdeset sela s kosovskog dijela ove regije gravitiraju gradovima Đakovici i Prizrenu (Krasniqi 1979:135 prema Bardhoshi 2004:99), a poznati su po tradicijskom bavljenju pekarstvom, odnosno odlasku muškaraca na sezonske i privremene radove. Slijedom navedenoga, tijekom zajedničkog suživota u Socijalističkoj Federativnoj Republici Jugoslaviji (SFRJ), Albanci su na prostor Republike Hrvatske dolazili iz Kosova (uglavnom zlatari katolici te pekari katolici i muslimani) i Makedonije (uglavnom slastičari muslimani), a s vremenom se i trajno naseljavali. ${ }^{2}$ Raspadom Jugoslavije 1990-ih, osamostaljenjem Hrvatske te poslije Kosova, ovi migranti postaju pripadnici nacionalne manjine. Da je riječ o sezonskim migrantima koji su s raspadom Jugoslavije odlučili zatražiti hrvatsko državljanstvo, sklone smo pretpostaviti na osnovi dvostrukog povećanja njihova broja u popisima stanovništva što je vidljivo u podacima Državnog zavoda za statistiku Republike Hrvatske (www.dzs. hr). Naime, godine 1981. u Hrvatskoj je živjelo 6006 Albanaca, a 1991. godine 12 032. Njihov se broj povećava i u sljedećim popisima; tako 2001. godine iznosi 15 082, a 2011. godine 17 513. Najveći broj živi na području Grada Zagreba-4292 stanovnika, dakle, na području koje je u fokusu ovog istraživanja.

\footnotetext{
${ }^{1}$ Regija Hasi nalazi se na prostoru današnjeg Kosova i Albanije. Kosovski dio poznat je pod nazivima Has ravnine (Hasi i rrafshit), Has Prizrena ili Has Đakovice, a albanski dio Hasi i Brisë ili Suhi Has (Hasi i thatë) (Bardhoshi 2004:99). Primjerice, procijenjeno je da je iz haških sela, Zyma i Damiana, 1947. godine na privremenom radu bilo oko 600 pekara (Filipović 1958:13 prema Tirta 2013:283).

${ }^{2}$ Na prostoru Hrvatske žive i Albanci koji su doselili iz Albanije. Najstarija albanska 'kolonija' u Hrvatskoj jesu Arbanasi. Danas se smatraju etničkim Albancima, a po nacionalnosti Hrvatima. Doselili su u prvim desetljećima 18. stoljeća u Arbanase, nekada prigradsko selo, a sada predgrađe grada Zadra. Više vidjeti: STIPČEVIĆ, Aleksandar. 2011. Tradicijska kultura zadarskih Arbanasa. Zagreb: Ibis grafika; PERIČIĆ, Šime. 1993. Pregled gospodarstva Arbanasa u prošlosti. Zadar: Mjesna zajednica Arbanasi.
} 


\section{METODOLOGIJA I CILJ ISTRAŽIVANJA}

\section{Dosadašnja istraživanja}

Procvatom obrade srebra na albanskom etničkom i povijesnom području te početkom njihove prepoznatljivosti na Balkanskom poluotoku smatra se 17. i 18. stoljeće (Mitrushi 1977:371). Prvi pronađeni esnaf (organizacijska jedinica obrtnika) u Albaniji, i na Balkanskom poluotoku, jest esnaf srebrnara grada Elbasana (1662. - 1900.). U isto vrijeme, kao najveći obrtnički centri navode se gradovi Skadar, Prizren, Berat i Voskopoja (ibid.). U dokumentu iz 1385. godine (Acta et diplomata res Albaniae mediae aetatis illustrantia. Vol. II) ${ }^{3}$ navodi se da su trgovci iz Drača (alb. Durrës) odlazili prodavati srebrne predmete i nakit u Ragusu (današnji Dubrovnik) (ibid.). ${ }^{4}$ Prvi albanski zanatlije obrađivali su srebro tehnikom filigrana ${ }^{5}$ i savat (mješavina srebra, bakra, olova i sumpora) za potrebe ukrasa na oružju (Mitrushi 1977). Procjenjuje se da je u 17. stoljeću obrada metala činila 17\% svih obrta navedenih gradova. Tada su u Prizrenu osnivane prve zanatske radnje obrade srebra, a bile su u vlasništvu obitelji Vuçaj i Shahta (Shkodra 1977) te obitelji Bashota, Shiroka, Shahini, Laçi, Bisaki, Bytyqi, Oroshi, Lleshdedaj, Nikolov, Spaqi, Gashi, Pali, Kërveshi, Qivlaku, Domniku, Perolli, Simoni itd. (Gashi 2012 prema Xhemili 2016). ${ }^{6}$ Većina njihovih potomaka i danas se bavi obradom srebra i zlata na Kosovu i/ili u Hrvatskoj. Ovaj podatak potvrdili su naši sugovornici, jer i sami pripadaju nekim od navedenih obitelji.

Iako su tijekom zajedničkog suživota u Jugoslaviji zlatari i pekari s Kosova zbog bolje zarade dolazili raditi u Hrvatsku, ove su teme bile u fokusu tek nekoliko istraživanja. Pojedini autori kao razloge neistraživanja navode

\footnotetext{
${ }^{3}$ Dostupno na: http://gallica.bnf.fr/ark:/12148/bpt6k5626777t (pristup 22. 3. 2017.).

${ }^{4}$ Zlatari iz Skadra trajno su se preseljavali u Dubrovnik od 1920-ih (usp. Lentić 1984:131).

5 "Filigran podrazumijeva tehniku izrade ornamentalnog nakita pomoću tankih komada žica kombiniranih malim kuglicama (granulama). Granulacija je izrada sitnih zrnaca od plemenitih metala i ukrasa na nakitu pomoću njihova lotanja na površinu... lotanje [je] postupak kojim se dijelovi kovina, polugotovog ili gotovog nakita spajaju u nerazdvojan spoj”. (Lešdedaj et al. 2015:9).

${ }^{6} \mathrm{O}$ dugoj tradiciji obrade srebra na području današnjeg Kosova svjedoče predmeti i nakit od ilirskih vremena, preko ranoga srednjeg vijeka, do suvremenosti, a čuvaju se u Muzeju Kosova u Prištini (Xhemili 2016).
} 
snažan utjecaj metodološkog nacionalizma unutar kojeg su se unutarnje migracije između republika SFRJ-a smatrale "uglavnom neproblematične i prirodne" (Kuti i Božić 2016:122), te činjenicu da su to bile sezonske migracije (Vadnjal 2014). Albanci s Kosova koji žive i rade na prostoru Hrvatske spominju se u kontekstu sezonskih migracija te slanja ekonomske pomoći članovima obitelji na Kosovu (Tirta 2013). Albanci u Hrvatskoj dio su ekonomskih migranata i pripadaju "staroj dijaspori" Kosova koja obuhvaća $14 \%$ sveukupnog iseljeništva (King i Vullnetari 2009). Suvremeni albanski autori bave se migrantskim ekonomskim doprinosom Kosovu. Naglašavaju da svaki treći Albanac iz Kosova živi i radi izvan domovine te da svaka obitelj ima barem jednog člana $u$ iseljeništvu (Paca 2015), dok doznake iz inozemstva čine četvrtinu nacionalnog dohotka (Hoti 2005:176). Albanci na prostoru Hrvatske istraživani su u okviru nacionalnih manjina Zagreba (Babić et al. 2011) i transnacionalnih praksi (Kuti i Božić 2016). Metodološki najbliže našem radu jest istraživanje Filigran: srebrna nit od Kosova do Istre (Lešdedaj et al. 2015) u kojem je dan i uvid u obiteljska migracijska iskustva te njihov život u Istri. Pored navedenih radova, koristile smo istraživanja o Albancima u Švicarskoj (Dahinden 2005; Heigl et al. 2011; Iseni 2013), Grčkoj (Gregorič Bon 2016) i Sloveniji (Vadnjal 2014) u kojima se autori bave ekonomskim migrantima, migrantskim mrežama, neformalnom poduzetničkom pomoći unutar etničke skupine, tj. financijskom podrškom proširene obitelji ili drugih članova iste etničke skupine, transnacionalnim vezama, tradicijskim obrascima po kojima migrant šalje financijsku pomoć obitelji u domovini, ljetnim posjetima migranata i njihovih obitelji kraju iz kojeg potječu itd. Ovi su nam radovi bili korisni za oblikovanje istraživačkih ciljeva te komparaciju i provjeru dobivenih podataka.

\section{Metodologija}

Istraživanje je provedeno od ožujka do prosinca 2016. godine, a temeljeno je na kvalitativnim intervjuima sa zlatarima - filigranistima (katolicima iz Prizrena) i pekarima (muslimanima iz regije Hasi). Kazivače smo birale tako da smo ulazile u zlatarske i pekarske radnje koje smo prepoznavale na osnovi njihovih prezimena. Kazivači, uglavnom vlasnici radnji, rođeni su na Kosovu ili su potomci ekonomskih migranata koji su tijekom suživota u Jugoslaviji sezonski radili u hrvatskim mjestima, posebice 
turističkim na jadranskoj obali. Kvaliteti dobivene građe doprinijelo je koautoričino albansko podrijetlo i intervjui na albanskom jeziku. Sveukupno je napravljeno jedanaest polustrukturiranih intervjua, šest sa zlatarima i pet s pekarima, i to na njihovim radnim mjestima. ${ }^{7}$ Iako smo u početku naumile imati kazivače obaju spolova, to se pokazalo teško izvedivim, jer su u zlatarnicama bili samo muškarci, a u pekarnicama uglavnom prodavačice Hrvatice i pekari Albanci. Intervjuirale smo jednu ženu koja je nedavno posao medicinske sestre na Kosovu zamijenila pekarskim poslom i radom sa suprugom u Zagrebu. Majstori zlatari rođeni su između 1938. i 1951. godine, dakle imaju od 66 do 79 godina. Iako odavno imaju uvjete za mirovinu, riječ je o zanatlijama koji s ljubavlju rade svoj posao i planiraju raditi "do kada će moći” kao što su to radili i njihovi predci. Za razliku od njih, pekari su mnogo mlađi, rođeni su između 1962. i 1979. godine. Kao oznake za kazivače koristit ćemo oznake spola M (muški) ili F (ženski), i prvo slovo zanimanja $\mathrm{Z}$ (zlatar) ili $\mathrm{P}$ (pekar), te godinu rođenja.

\section{Cilj istraživanja i teorijski okvir}

Istraživanje smo ciljano bazirale na migrantima i njihovim potomcima iz dvije zanatske skupine. Cilj je rada na osnovi etnografije pojedinačnoga (ethnography of the particular, Abu-Lughod 1991), preko življenih

\footnotetext{
${ }^{7}$ Prema podacima Udruženja obrtnika grada Zagreba (www.obrtnici-zagreb.hr/) koje smo dobile na upit preko e-maila, u gradu Zagrebu ima 93 pekarska i 65 zlatarskih obrta. U statistikama ne vode podatke o etničkoj pripadnosti vlasnika te ne postoje podaci koliko je vlasnika Albanaca. Sukladno Zakonu o zaštiti osobnih podataka, nisu nam mogli dati uvid u imena i prezimena vlasnika da na osnovi njih same prepoznamo albanska prezimena i imena. No, na našu je zamolbu jedna službenica uvidom u podatke o imenima i prezimenima sama procijenila da od 93 vlasnika pekarskih obrta 79 imaju albanska imena i prezimena, te od 65 zlatarskih obrta 7. Budući da nam se broj zlatara činio jako malen, zamolili smo je da ponovno provjeri i kao pomoć smo poslale 7 prezimena naših kazivača (s jednom se obitelji kontaktiralo naknadno, te podaci nisu uvršteni u rad), nakon čega je poslala novi podatak da su članovi obitelji s tih 7 prezimena vlasnici 27 zlatarskih obrta. Najljepše zahvaljujemo na ovim okvirnim podacima. Prema našoj procjeni na osnovi pretraživanja naziva radnji i prezimenima vlasnika zlatarnica na tražilici Google, smatramo da su, kao i kod pekara, albanske obitelji vlasnici većine zlatarskih obrta u gradu Zagrebu. Ni ostale hrvatske institucije s kojima smo kontaktirale, primjerice Hrvatska gospodarska komora, Hrvatska obrtnička komora i Registar poslovnih subjekata, nemaju podatke o etničkoj pripadnosti vlasnika obrta.
} 
migrantskih i manjinskih iskustva, prikazati uzroke migracija i remigracija, etničko poduzetništvo te njihovu svakodnevicu u Zagrebu. U istraživanju smo koristile teoriju migracijskih sustava, odnosno promatrale smo makro-, mezo- i mikrostrukture koje su utjecale na odluku o migraciji (Castles i Miller 2003:28; Brettell 2003:2-6). Makrostruktura obuhvaća politički i ekonomski kontekst migracije (Brettell 2003:2). Migracije kojima se bavimo započele su tijekom suživota u istoj državi Jugoslaviji kada su Albanci iz autonomne pokrajine Kosovo (kao sastavnog dijela Republike Srbije) migrirali u Republiku Hrvatsku. Raspadom Jugoslavije, Ustavom Republike Hrvatske od 22. prosinca 1990., ${ }^{8}$ osamostaljenjem Republike Hrvatske te Ustavnim zakonom o ljudskim pravima i slobodama i o pravima etničkih i nacionalnih zajednica ili manjina u Republici Hrvatskoj (1991.), Albanci su u Hrvatskoj dobili status nacionalne manjine. ${ }^{9}$ Temeljem Zakona o hrvatskom državljanstvu, ${ }^{10}$ velik dio ovih migranata zatražio je hrvatsko državljanstvo, na što su imali pravo prema članku 8. navedenog Zakona, odnosno temeljem dugotrajnog boravka u Hrvatskoj. ${ }^{11}$ U kontekstu mezostruktura zanimali su nas odnosi između pojedinaca u obiteljskim i rodbinskim grupama, susjedstvu, a kroz mikrostrukture promatrale smo neformalne migrantske mreže koje su stvorili migranti (Brettell 2003:6). Migrantske mreže jesu čvrste veze između pojedinaca,

8 Narodne novine (NN) 56/90, http://narodne-novine.nn.hr/clanci/ sluzbeni/1990_12_56_1092.html.

${ }^{9} \mathrm{NN}$ 65/91, 27/92, 34/92, http://narodne-novine.nn.hr/clanci/sluzbeni/1992 $06 \quad 34896$. html. Također vidjeti: Perić Kaselj et al. 2015.

${ }^{10}$ Zakon o hrvatskom državljanstvu, NN 53/91, 70/91, 28/92, 113/9 - Odluka USRH, 4/94 - Odluka USRH, 130/11 i 110/2015.

${ }^{11}$ Prema istom zakonu, članku 8a, u trenutku podnošenja zahtjeva osoba je morala imati otpust iz stranog državljanstva ili dobiti dokaz da će otpust dobiti ako bude primljen u hrvatsko državljanstvo. U praksi bi to značilo da su Albanci iz Kosova trebali dobiti otpust iz prethodnog državljanstva. No to ne znači da ga poslije nisu mogli ponovno zatražiti, posebice nakon osamostaljenja Republike Kosova. Svi kazivači zlatari imaju samo hrvatsko državljanstvo, osim jednog koji je u Hrvatsku doselio posljednji (1972. godine) i koji ima oba državljanstva. Tri kazivača pekara i kazivačica imaju dvojno državljanstvo, hrvatsko i kosovsko, a dva pekara, koji su posljednji migrirali, imaju samo kosovsko državljansvo. Od njih dvoje jedan preko 30 godina živi u Republici Hrvatskoj i vlasnik je pekare, a drugi osam godina radi kod rođaka. 
skup rodbinskih i prijateljskih odnosa, a karakterizira ih visok stupanj povjerenja, komunikacije i ispomoći (usp. Klvanova 2010). Zanimalo nas je koliko su one pridonijele odluci o migraciji i prvim danima života u novim prostorima, odnosno jesu li migranti jedni drugima osiguravali smještaj, posao, prenosili vještine zlatarskog i pekarskog zanata te se zapošljavali unutar obitelji i etničke zajednice itd. Nadalje, zanimale su nas migrantske prakse i društveni odnosi kojima migranti povezuju države/mjesta rođenja i sadašnjeg življenja što smo promatrale na individualnim mikrorazinama (usp. Glick Schiller i Çaglar 2009:184; Kuti i Božić 2016:19) koristeći transnacionalnu teoriju (usp. Levitt i Glick Schiller 2004; Faist et al. 2013; Čapo Žmegač 2003). Transnacionalna teorija podrazumijeva da migranti, odnosno transmigranti, povezuju zemlje podrijetla i primitka, da razvijaju i održavaju višestruke obiteljske, organizacijske, ekonomske i dr. veze koje nadilaze granice država, odnosno spajaju ih (usp. ibid.). Kazivače smo pitale održavaju li i kako kontakte s obitelji u mjestu podrijetla, prate li i kako događanja na Kosovu, posjećuju li rodno mjesto itd. Pritom nam je cilj bio promatrati smanjuju li transnacionalna bivanja $u$ dvama prostorima navedene aspekte integracijskog procesa (Mügge 2016). Budući da su naši kazivači privatni poduzetnici koji se s tradicijski prenošenim zanatskim vještinama samozapošljavaju, zanimalo nas je koliko to utječe na njihovu društvenu i kulturnu integraciju u hrvatsko društvo (usp. Esser 2001:16, prema Penninx i Garcés-Mascareñas 2016:13). Da bismo to istražili, propitivale smo i granice društvenih zajednica, odnosno koga biraju za bračnog druga, kojim jezikom govore, participiraju li u manjinskim udrugama, te kako is kim provode slobodno vrijeme. Pritom smo pozornost obratile na duljinu njihova boravka u Zagrebu.

\section{Migracije albanskih pekara i zlatara u Hrvatsku}

Bazirajući se na neoklasičnom pristupu ekonomskih teorija migracija, geografske razlike u zahtjevima i ponudama na tržištu rada glavni su razlog migracija: "Regije s nedostatkom posla u odnosu na kapital, suočene su s niskom ravnotežom plaća. Ova razlika u plaćama uzrokuje migracijski tok iz regija s niskim plaćama prema regijama s visokim plaćama" (Bauer i Zimmermann 1995:96). Budući da je Kosovo bilo najslabije ekonomski razvijena savezna jedinica u Jugoslaviji, kroz ovaj kontekst 
mogu se promatrati i migracije albanskih pekara i zlatara iz Kosova u Hrvatsku (Vathi i Black 2007). Dakako, smještaj Kosova i Hrvatske u Jugoslaviji pogodovao je brojnim migracijama unutar iste države. I druge političke okolnosti sredinom 20. stoljeća, primjerice iseljavanja talijanskog stanovništva (Dota 2010), omogućile su Albancima zlatarima i filigranistima jednostavniji pronalazak poslovnih prostora, kao što za Istru navode Lešdedaj et al. (2015:18). Migracije u Istru počele su ranih 1950-ih godina i trajale do kraja 1970-ih, a privlačan faktor bio je razvoj turizma na jadranskoj obali (ibid.:22). U istom razdoblju, bilo u Istru ili u druga jadranska mjesta, dolazili su i predci kazivača.

Prve migracije karakterizira sezonski dolazak majstora zlatara filigranista. Naši kazivači zlatari u Hrvatsku su doseljavali mladi, tijekom osnovne škole, gimnazije ili su ovdje rođeni. Prije dolaska u Zagreb, skoro su svi ovdje imali člana obitelji. Prije stalnog preseljenja u Zagreb, bilježimo brojna migracijska iskustva, no, kao što se vidi iz kazivanja, privlačna odredišta bile su morske destinacije ili glavni grad: "Ja sam došao u Zagreb 1972. godine... Naši stari su rekli: 'Kad se preselite, ili idite do kralja ili do mora'." 12 (ZM, 1938.). Predci nekoliko kazivača radili su u Rovinju, a danas ondje imaju rodbinu. I drugi autori navode da migracije zlatara karakteriziraju relacije obala (Istra) - Zagreb (Kuti i Božić 2016:152).

Privremeno i sezonski dolazili su muškarci, a kada je donesena odluka o trajnom preseljenju, dolazile su i supruge s djecom:

"Najprije je moj djed s bratom došao prodati filigran na Krku i Rabu (negdje 1920-ih, 1930-ih). Poslije 1939. godine odlučili su doći u Zagreb, međutim još su bili povezani s Prizrenom jer je ostali dio obitelji bio tamo. Mislim da je baka došla 1942. ili 1943. godine.” (ZM, 1953.)

Kazivači pekari na Kosovu su živjeli u mnogočlanim obiteljima zadružnog tipa iz kojih su tradicionalno migrirali samo muškarci. Odlazili su u grupama te na novoj destinaciji zajedno stanovali u unajmljenom stanu ili kući. Ovo su bile privremene, rotirajuće migracije, na način da su se muškarci iz obitelji, tj. kako objašnjavaju - iz "zajedništva", svakih

12 "Në rast shpërnguljeje, ose shkoni te mbreti ose te deti." 
nekoliko tjedana do mjeseci, ovisno o potrebi, rotirali - dolazili i odlazili kući. Tijekom izbivanja muškaraca, žene i djeca stalno su živjeli na Kosovu: “... žene su ostale kod kuće. Takva je bila tradicija da su samo muškarci išli van raditi” (PM, 1967.). Ta se tradicija, prema istom kazivaču, održala do odvajanja u nuklearne obitelji (roditeljski par s djecom). Tada su žene trajno migrirale sa supruzima. Ovisno od obitelji do obitelji takva obiteljska osamostaljenja događala su se kako su se sinovi ženili. Međutim, ovakve prakse zadržale su se i do danas. Kazivač koji je došao posljednji 2009. godine, potvrdio je jednak obrazac privremene muške migracije i dislociranoga obiteljskog života, odnosno život svoje višečlane i višegeneracijske obitelji. On i njegova dva brata rade kod različitih članova obitelji, on u Hrvatskoj, braća u Crnoj Gori, a njihove supruge s djecom, svekrom i svekrvom žive u istoj kući na selu u Hasiju:

“Od 2009. radim tu kod ujka. Kući idem ovisno o dogovoru, može biti da radim četiri mjeseca pa idem tamo mjesec i pol, sve ovisi o plaći i o dogovoru sa šefom... Ne, moja žena nije nikad tu bila u posjetu." (PM, 1979.)

Naši kazivači i/ili njihovi preci doseljavali su na prostor Hrvatske u razdoblju od 1939. do 2009. godine. Prilikom dolaska veliku su ulogu imale migrantske mreže. Naime, svi doseljenici, osim jednoga, ovdje su imali obitelj ili blisku rodbinu koje su im osigurale posao i smještaj. Tri kazivača došli su direktno s Kosova u Zagreb, dok su ostali prije stalnog preseljenja u Zagreb remigrirali s drugih mjesta u Hrvatskoj, uglavnom obalnih ili iz drugih država jugoistočne ili srednje Europe. Prema objašnjenjima svih kazivača, Hrvatska ih je privlačila stoga što je bila "najjača država u Jugoslaviji” i tu su vidjeli najveću ekonomsku perspektivu.

Iz kazivanja možemo zaključiti da su kod obje grupe zanatlija migracije poticane i olakšavane solidarnošću proširene obitelji i članova iste etničke zajednice oko zapošljavanja i/ili prikupljanja početnog kapitala za kupnju radnje. Riječ je o bounded solidarity (obvezujuća solidarnost) - neformalnim društvenim odnosima, obiteljskim i rodbinskim vezama $i$ vrijednostima, kroz različite vrste pomoći, uključujući financijsku potporu od pripadnika iste etničke skupine na početku migracijskog iskustva (Portes 1998 i Jahnsen 2000 prema Dahinden 2005:197, 200). Jednake prakse 
albanskih poduzetnika tijekom 20. stoljeća zabilježene su i u Sloveniji (Vadnjal 2014).

Izneseni podaci o dolasku mladih muškaraca, što se prakticira i danas, njihovim privremenim radovima na prostoru Hrvatske te tek kasnijem dolasku žena (što se događa nakon odluke o stalnom preseljenu), pojašnjavaju i statističke podatke da je albansko stanovništvo u Hrvatskoj mlađe od prosjeka ostalog stanovništva te da kod njih pronalazimo najveću neravnotežu po spolu u korist muškaraca. Tako su 2011. godine u Hrvatskoj žene činile 51,8\% ukupnog stanovništva ( $\underline{\text { www.dzs.hr }}$ ), a Albanke svega $44,3 \%$ od ukupnog broja pripadnika albanske manjine.

\section{Albanski poduzetnici u Zagrebu: običajno prenošenje specifičnih znanja i vještina te etničko poduzetništvo}

Svi pekari navodili su prenošenje zanata kroz više generacija svojih obitelji te iskustvo sezonskih ili privremenih migracija kod drugih članova obitelji, na Kosovu ili u Hrvatskoj: "Ja pripadam osmoj generaciji koja se bavi pekarstvom i još sam naslijedio dalje zanat” (PM, 1971.). Samo je jedan kazivač radio isti posao u mjestu rođenja. Godine 2000., nakon rata na Kosovu i velike ekonomske krize, prvo je suprug otišao privremeno raditi na hrvatsku obalu, nakon toga se obitelj trajno preselila u Zagreb, kao što je supruga objasnila:

"Moj je muž radio u državnoj pekari na Kosovu i onda nakon privatizacije ostao je nezaposlen i odlučio se preseliti u Hrvatsku. Iako mi i prije, kao obitelj, imali smo dućan na Pagu.” (PF, 1962.)

Većina zlatara - filigranista zanate je učila u obitelji, nakon čega su se usavršavali kod drugih majstora u Hrvatskoj, Austriji, Italiji i Njemačkoj. Jedan kazivač prije dolaska u Hrvatsku učio je i radio u Kooperativi srebra "Filigran" u Prizrenu. Nakon stečenog iskustva, naši kazivači otvorili su zlatarnice u Zagrebu. Svi zlatari, osim jednoga koji je završio formalno školovanje u Zagrebu, zanat su učili isključivo privatno kod drugih majstora, odnosno prolazili šegrtovanje u više radnji. Posljednja dva desetljeća imamo dvostruke prakse, formalnog i neformalnog obrazovanja. Djeca kazivača nakon završenih raznih fakulteta (u jednom slučaju u inozemstvu) upisuju izvanredno školovanje za zlatara te polažu samo završni ispit, dakle 
svu praksu stječu neformalnim putem. Razgovarajući o tehnikama izrade nakita, saznaje se da su neki specijalizirani za pojedine tehnike izrade i/ili sirovine (filigran, srebro, zlato, dragulji...). Iako su se u ranijim razdobljima oba zanata učila kod rodbine ili obiteljskih prijatelja, kod zlatara se to danas manje prakticira, dok je to kod pekara još ustaljena praksa. Kod pekara, danas dolaze brojni mladi rođaci iz Kosova koji povremeno pomažu. Nakon stjecanja radnog iskustva, otvaraju svoje radnje, te u njih na praksu primaju mlađe rođake. Dakle, razlike između kazivača iz ove dvije skupine zanatlija jesu u tome da su zlatari na hrvatsko područje doselili ranije, a doseljavanje pekara traje i danas. Budući da nakon osamostaljenja Kosovari za Republiku Hrvatsku trebaju imati vizu, radne su migracije otežane. ${ }^{13}$

Većina je zlatara vlastitu radnju imala već u dvadesetim godinama života. Financijsku osnovu za njezino otvaranje osiguravala im je (proširena) obitelj i prijatelji, što ih svrstava u takozvani Ethnic Minority Entrepreneur - etničko manjinsko poduzetništvo, termin koji se odnosi na formalne i neformalne aktivnosti ovisno o legalnom statusu, ekonomskim izvorima i pristupu mrežama za podršku unutar etničke skupine (Lazardis i Koumandraki 2003, prema Vadnjal 2014). Etničko poduzetništvo često se naziva i obiteljsko poduzetništvo uzimajući u obzir oslanjanje na obitelj i druge osobe unutar društvene mreže i to prilikom raznih vrsta pomoći (Bhalla et al. 2006, prema Vadnjal 2014). Već smo naveli da majstori zlatari koji rade u centru grada Zagreba spadaju u skupinu treće životne dobi, no zbog ljubavi prema svom poslu i dalje ga s ponosom rade, kao što su to uostalom radili i njihovi predci. Ovi privatni poduzetnici i vrsni zanatlije sami biraju kada će se povući iz aktivnog rada što možemo promatrati i kao etnički i tradicijski oblik aktivnog starenja. Zlatari su navodili da njihove obitelji imaju od tri do sedam radnji, od kojih su neke u Zagrebu, a neke na obali. ${ }^{14}$ Jedna obitelj u istom obalnom gradu ima tri

${ }^{13}$ Republika Hrvatska uspostavila je 30. lipnja 2008. diplomatske odnose s Republikom Kosovom. Više o dobivanju hrvatskih viza vidjeti na stranicama Ministarstva vanjskih i europskih poslova RH (crovisa.mvep.hr) i Veleposlanstva RH u Prištini (ks.mvep.hr).

${ }^{14}$ Za ove smo podatke slučajno dobili potvrdu i od Udruženja obrtnika grada Zagreba. Kazivači su objasnili da poneke obitelji imaju više radnji u samom centru grada. Međutim, razvojem trgovačkih centara, i oni su se prilagodili te u njima kupili poslovne prostore kojima su vlasnici i/ili u kojima rade njihove supruge i/ili djeca. U takvim radnjama 
zlatarnice. ${ }^{15}$ Dakle, unatoč formalnom stalnom boravištu u Zagrebu, dio obitelji u ljetnoj turističkoj sezoni živi u drugim mjestima, odnosno i danas prakticiraju sezonski rad i dislocirani obiteljski život.

Da ovakve prakse nisu samo u Zagrebu pokazuju istraživanja provedena s drugim albanskim migrantima. U Švicarskoj se Albanci profesionalno i obiteljski čvrsto oslanjaju na druge pripadnike svoje etničke grupe. U etničkoj zajednici dobivaju ekonomsku i emocionalnu podršku i zajedno provode slobodno vrijeme (Dahinden 2005:200). Jednake rezultate pronalazimo i u Sloveniji, s time da istraživanje nije uključilo zlatare, nego pekare, slastičare, trgovce voćem i povrćem, brzom hranom itd. (Vadnjal 2014)

Kazivači su preselili u Zagreb iz drugih mjesta. Oni koji su došli u Zagreb prije osamostaljenja Republike Hrvatske, došli su zbog uspjeha i nakon stjecanja početnog kapitala. Međutim, neki su radili u drugim hrvatskim gradovima te su preselili u Zagreb nakon početka ekonomske krize od 2009. na ovamo, ${ }^{16}$ kao što je vlastito iskustvo objasnio pekar:

"Radio sam 27 godina u Ogulinu (Vrbovska) i prije pet godina sam odlučio doći u Zagreb jer ne možeš više tamo preživjeti. Kriza je počela prije deset godina, ali posljednjih pet godina je katastrofa". (PM, 1971.)

Ekonomska kriza nije važna samo zbog profita obrtnika nego se pokazala i bitnim faktorom u nasljeđivanju zanimanja:

uglavnom se (pre)prodaje industrijski i dizajnerski nakit te satovi, dok u starim radnjama u centru grada pronalazimo zanatski izrađene primjerke. Dakako, s padom kupovne moći i zbog neprepoznavanja finoće izrade nakita, i u centru se nude povoljniji industrijski nakit i replike, odnosno strojne izrade tradicijskih tehnika izrade nakita, pa i filigrana. Iako to nije primjer kod naših kazivača, zbog tranzicijskog razdoblja u poslijeratnoj Hrvatskoj te višegodišnje gospodarske krize, neke su se obitelji prestale baviti zlatarstvom te su u poslovnim prostorima otvorile mjenjačnice, fotokopiraonice, trgovine drugom robom ili su se preorijentirale na ugostiteljstvo.

${ }^{15}$ Pod obiteljskim radnjama, osim radnji braće, sestara, supružnika i djece, smatraju i radnje članova proširene obitelji, npr. ujaka, stričeva.

${ }^{16} \mathrm{O}$ ekonomskoj krizi kao najvećem problemu s kojim se danas suočavaju Albanci u Hrvatskoj vidi: Babić et al. (2011:265). 
"Kći mog brata završila je školu primijenjene umjetnosti i onda je nastavila školu za ovaj zanat u Italiji. Danas radi tu kod brata. Moje dvije kćeri završile su elektrotehniku i ekonomiju jer tada nije bilo perspektive za zanat, a danas kad je počelo opet ići na dobro, mlađa kći već se počela interesirati." (ZM, 1953.)

"Kći se školovala za umjetnost i radi tu više, a sin je završio za draguljara." (ZM, 1950.)

Svi su zlatari navodili važnost školovanja te završeno fakultetsko obrazovanje djece. Djeca koja se nastavljaju baviti obiteljskim poslom, često se školuju i u inozemstvu.

Velik broj kazivača pekara navodio je da njihova djeca znaju njihov posao, međutim i oni i djeca ga smatraju teškim i neisplativim za budućnost:

"Općenito djeca žele imati više luksuzan život, a pekarstvo je jako težak zanat. Trebaš raditi mnogo, preko noći i uvijek biti jako, jako precizan.” (PM, 1967.)

“... naravno, čak i da bih samo dvije moje kćeri ostavio, slobodno mogu ići dolje [na Kosovo].” (PM, 1971.)

Kao što se vidi iz navedenih citata, danas oba zanata uče i nasljeđuju sinovi i kćeri. Međutim, u ranijim razdobljima rijetke su se žene bavile navedenim zanimanjima. Dakako, postoje izuzeci. Sestre dvaju zlatara s kojima smo razgovarali, te jedna supruga, vlasnice su zagrebačkih zlatarnica. Za jednu od njih, brat nam je rekao da je bila jedina žena $u$ Jugoslaviji koja je imala certifikat za draguljara. O svojim majkama koje su bile majstorice ili pomoćnice u radnjama filigrana, govorili su i neki albanski filigranisti iz Istre (Lešdedaj et al. 2015:13).

Zbog prirode posla, zlatari rade sami, dok im u prodaji pomažu supruge, djeca ili imaju zaposlenike Hrvate. Pekari za prodaju također preferiraju Hrvate: "Uvijek smo imali Hrvate za prodaju. Bolje je i zbog jezika i lakše je zaposliti zbog dokumentacije." (PF, 1962.). Na pitanje je li im etnička pripadnost važna kod odabira radnika, jedan je kazivač odgovorio: "Kod mene uvijek u svemu Albanci imaju prednost.” (PM, 1967.)

Prema navedenoj građi, vidimo da su kod obje skupine migranata/ zanatlija prisutni jednaki tradicijski obrasci obiteljskog, odnosno etničkog 
poduzetništva i obvezujuće solidarnosti. Promjene su vidljive s obzirom na spol djece; posljednjih desetljeća sva djeca mogu nastaviti obiteljsko poduzetništvo. U kontekstu hrvatske gospodarske krize i smanjivanja platežne moći, i ovi se obrtnici prilagođavaju tržištu te obrtnička umijeća dopunjuju ili zamjenjuju trgovačkim djelatnostima.

\section{Bračni život i način provođenja slobodnog vremena}

Albanski zlatari i pekari dvije su specifične migrantske skupine koje na osnovi svojih tradicijski prenošenih zanatskih umijeća i obiteljske ekonomske pomoći zapošljavaju sebe, svoju obitelj, ostale pripadnike etičke skupine te u manjem broju domicilno stanovništvo. Upravo zbog toga, u ovom nas je radu zanimalo jesu li ove dvije grupe zanatlija zatvorene u svoje strukovne, etničke i konfesijske zajednice. To smo propitivale istražujući s kim sklapaju brakove, kojim jezikom/jezicima govore te kako i s kim provode slobodno vrijeme. Kroz odgovore na ova pitanja željele smo saznati njihovu društvenu i kulturnu integraciju. Nadalje, zanimale su nas transnacionalne prakse i to koliko njihova prisutnost (ne)utječe na proces integracije, te kako je na te prakse utjecala promjena političkog konteksta.

Svi su pekari isticali da im je važno da se "njihova kultura čuva što više". Da bi "očuvali svoju kulturu" nastoje da njihova djeca na Kosovu završe osnovnu školu, gimnaziju i/ili fakultet, a želja im je i da sklope brak s Albancima, kao što su i oni.

"Ja želim da i moje kćeri i sinovi uđu u brak s Albancima. Za mene je nesreća ako će se udati ili oženiti s Hrvatom, Srbinom ili Nijemcem... zanima me samo narodnost, jer vjeru ima svaki između četiri zida i nema zašto bi nekoga to zanimalo.” (PM, 1975.)

"Ja se nisam miješala na njihovu odluku. Sva tri sina sami su odlučili za Albanke, ali po mojem mišljenju najbolje tako svaki sa svojim... ako se želi da se čuva kultura i jezik.” (PF, 1962.)

Osim što su im bitni etnički homogeni brakovi, jedan kazivač naveo je da je bitna i pripadnost istoj vjerskoj zajednici: "Za društvo nije mi problem bilo tko, ali za brak ne bih htio miješati vjeru. Drukčija je kultura." (PM, 1971.). Svi pekari unutar obitelji pričaju na albanskom jeziku. 
Unatoč željama roditelja, zlatari smatraju da odluka o odabiru bračnog druga pripada djeci: "Nije važno... moja je želja da budu Albanci i reći ću, ali u ljubav ja se ne mogu miješati.” (ZM, 1943.).

Dva su zlatara oženjena Albankama, od toga je jedna rođena $\mathrm{i}$ odrasla u Australiji te ne govori albanski jezik. Ostali zlatari oženjeni su Hrvaticama. Svi su objasnili da su u Hrvatskoj imali male svadbe, i da na njima nije bilo elemenata albanskih tradicijskih svadbi. Djeca samo jednog zlatara govore albanski iako ga, prema objašnjenjima očeva, većina razumije. Tijekom istraživanja nismo naišli na brakove sklopljene između ovih dviju istraživanih skupina.

Obiteljska okupljanja zlatara katolika uobičajena su za proslave godišnjih običaja poput Božića i Uskrsa. Tim prigodama njihove supruge Hrvatice pripremaju i albanske specijalitete, prisutni pjevaju albanske pjesme itd. "Uvijek za Uskrs je pogača i laknor ${ }^{17}$... da, moja žena koja je Hrvatica je to naučila i ona kuha." (ZM, 1950.). Obitelj jednog zlatara slavi "krsnu slavu". Za njegovu obitelj, već generacijama zaštitnik je sveti Nikola. Taj mu dan na večeru dolaze obitelj i prijatelji, za koje on svira i pjeva $i$ albanske pjesme: "Tu u Hrvatskoj, ovaj blagdan se izgubio, a mi još kao u Srbiji i u Crnoj Gori, još čuvamo i slavimo za blagoslov kuće.” (ZM, 1951.).

Najstariji zlatar (r. 1938.) naveo je običaj Piri i kujunxhive koji se obilježavao 14. rujna. Kazivač se sjeća, kada je on bio mladić u Prizrenu, nekoliko dana prije 14. rujna dva srebrnara obilazila su druge zanatlije i skupljali novac u potë (posudu u kojoj se topi zlato i srebro) koja se poslije dala svećeniku da novac podijeli siromašnima. Kako nam je objasnio, danas se promijenio humani karakter ovog običaja, i ostala je samo tradicija da se skupina zlatara i filigranista susretne u nekom mjestu u Hrvatskoj ili Sloveniji. Budući da 14. rujna traje turistička sezona, okupljanje su preselili na prvu subotu u listopadu. Većina sudionika prijatelji su iz djetinjstva i bili su članovi kulturnog društva "Agimi” u Prizrenu. Prilikom okupljanja pjevaju albanske pjesme te pričaju o uspomenama iz djetinjstva i mladosti.

Iako su danas Hrvatska i Kosovo samostalne države, većina pekara prakticira paralelni život na oba mjesta; kako su objasnili, žive "pola tamo",

${ }^{17}$ Laknor je Albanski tradicionalni specijalitet sličan piti. Radi se od kukuruznog brašna, puni špinatom ili porilukom i prelijeva kiselim mlijekom. 
isto kao što su to prakticirali i tijekom suživota u istoj državi, Jugoslaviji. Većina kazivača dva do tri puta godišnje odlazi u rodni kraj, sve životne običaje (npr. svadbene i pogrebne) prakticiraju u mjestu rođenja i godišnje odmore provode u starom kraju. Ovi im posjeti služe za različite društvene procese (čuvanje obiteljskih veza), kulturne (upoznavanje s tradicijom i "korijenima"), ekonomske (cirkulacija novca) i transnacionalne prakse (posebice kontakte s rodbinom u više mjesta) (Kadriu 2013:313). Iako su danas formalno državljani Republike Hrvatske, kod nekih pekara i danas je riječ o praksi privremenih i/ili sezonskih migracija u Hrvatsku. Osim toga, na Kosovu im žive supruge i djeca. Razlog zašto i danas prakticira ovakav način života jedan je kazivač objasnio:

"Ja sam proveo moju mladost u migraciji pa nisam htio da i moja djeca isto. Dobar ili loš, kako god bio edukacijski sustav tamo, htio sam da oni tamo studiraju. Također tako i neće izgubiti jezik." (PM, 1967.).

Zlatari rijetko putuju na Kosovo. Najčešći su odgovori bili od jednom u deset godina, do jednom godišnje, uglavnom za Dan mrtvih (1. studenoga), i tada obilaze obiteljske grobnice te rođake. Kazivači su objasnili da nastoje "barem jednom u životu odvesti djecu da vide odakle su podrijetlom". No, dakako, i ovi posjeti zavise od pojedinca:

"Dva-tri puta godišnje idem jer otac mi je pokopan u Prizrenu. Nastojim otići jednom, a ostalo kad imam slobodnog vremena... od 20. godišnjice mature, slavili smo svakih pet godina. Evo prije dvije godine smo imali 50. godišnjicu i svi smo se skupili i ostali tjedan dana tamo." (ZM, 1943.).

Za razliku od pekara, zlatari na Kosovu nemaju nekretnine. Smatraju da je njihov život isključivo u Zagrebu. Na pitanje bi li se vratili živjeti na Kosovo, odgovorili su da ne: "Pa ja ne mogu se vratiti više. Možda pet dana, ali ne... život mi je tu." (ZM, 1951.).

Pekari muslimani okupljaju se za Bajram i Novu godinu. Tim prigodama našim kazivačima u goste dolazi proširena obitelj čiji članovi žive u Hrvatskoj i Sloveniji. Sve životne običaje (zaruke, svadbe, sahranjivanja) kao i obrezivanja dječaka obavljaju u rodnom kraju gdje, 
kako ističu, prakticiraju "sve tradicije što Hasi ima". Isticali su da oni i u Zagrebu prakticiraju tradicionalniji način života objašnjavajući da je prema njihovom mišljenju ruralna regija Hasi izolirana i "mnogo tradicionalnija od ostatka Kosova". Pod time su objasnili zajednički život nekoliko oženjene braće i roditelja, važnost riječi i odluke starih osoba, običajno pravo nasljeđivanja, solidarnost između članova proširene obitelji, odnosno više obitelji itd. Jedna od "tradicija" koju prakticiraju jest financijska podrška obitelji na Kosovu. Isti podatak spominje se u svim radovima koji analiziraju transnacionalne veze albanskih migranata, u Hrvatskoj, Sloveniji, Švicarskoj i općenito Albanaca po Europi i SAD-u, što govori o njihovim čvrstim vezama sa zemljom podrijetla i obitelji (usp. Vadnjal 2014, Heigl et al. 2011 itd.).

Jedan je kazivač kazao: "Sad se sve promijenilo, ali nekako kod nas još ima reda, jer stari se slušaju. Tu nitko te ne zna." (PM, 1976.). Ovakav njihov izbor ujedno sprečava i integriranje. Iako pekari žive u etnički i konfesijski homogenim zajednicama, svi su navodili da se dobro osjećaju u Zagrebu. Nitko nije naveo primjer diskriminacije. Samo je jedan pekar uputio na to da se općenito osjeća neravnopravan u odnosu na Hrvate te objasnio: "Trebaš biti dva puta bolji od nekog Hrvata da budeš ravnopravan... za svašta." (PM, 1976.).

Tijekom razgovora s pekarima uočile smo nostalgičnost za rodnim krajem. Navodili su da im nedostaje zrak, "osjećaj doma”, priroda, "sir i paprika, koji ovdje nemaju isti ukus kao u domu": "Možda tu mogu jesti svaki dan meso, ali tamo samo kruh i sir mi se čini bolje.” (PM, 1971.). Usprkos nostalgiji i želji da njihova djeca sklope brak s Albancima, samo jedan pekar, sezonski radnik s najkraćim stažem od osam godina, planira se vratiti na Kosovo. Većina planira trajno živjeti u Zagrebu, a svi su kao razlog naveli veće zarade. S druge strane, zlatari su mnogo manje povezani s Kosovom, nitko od kazivača nije pokazivao nostalgiju, dapače, isticali su da "sve što im je najvažnije u životu imaju u Hrvatskoj" te da njihova djeca žive ovdje.

Obje istraživane skupine kroz medije prate vijesti o Kosovu, a zbog razvoja virtualnih društvenih mreža (npr. Facebooka) često kontaktiraju s obitelji u domovini. Razvoj telekomunikacijskih tehnologija (poput Skypea, Vibera, WhatsAppa) pokazao se kao najizraženiji oblik transnacionalne 
aktivnosti u socijalnoj i kulturnoj sferi (također usp. Kuti i Božić 2016:165167).

Iz navedenih primjera kazivanja, vidljivo je da su albanski zlatari katolici iz Prizrena mnogo više društveno i kulturno integrirani u hrvatsko društvo. Kazivači zlatari smatraju se potpuno identifikacijski integrirani u Zagrebu, odnosno imaju subjektivan osjećaj pripadanja (usp. Esser 2001:16, prema Penninx i Garcés-Mascareñas 2016:13). Tijekom razgovora naglašavali su velike sličnosti s Hrvatima te isticali katoličku vjeroispovijest, vlastita nastojanja prilagodbe i negirali diskriminaciju. Svoj primjer objasnio je jedan kazivač: "Pa nije fer, kad dolaziš negdje trebaš se naviknuti tom društvu, ni svi Albanci tu nisu vrhunski... ne, ja nikad nisam imao nešto da bih rekao diskriminacija" (ZM, 1951.).

Što se tiče slobodnog vremena, svi zanatlije govorili su da ga imaju malo. Pekari su naveli da se većinom druže s drugim Albancima, a zlatari da se druže s Albancima i Hrvatima:

"Imam jako dobre odnose s drugim filigranistima ali ne družimo se mnogo... Ja se više družim s Hrvatima ili drugim prijateljima Albancima kod kojih idem i koji mi dolaze za fešte, rođendane, večere i sl." (ZM, 1943.).

Prilikom obiteljskih druženja pekari govore na albanskom jeziku te prakticiraju istu tradiciju kao na Kosovu, npr. konzumiraju ruski čaj ${ }^{18}$ koji piju na turski način, ${ }^{19}$ pripremaju tradicionalna albanska jela. U druženjima sa sunarodnjacima zlatari također uglavnom govore albanskim jezikom. Jedan je zlatar pojasnio: "Naravno da pričamo na albanskom, pa ja još mislim na albanskom.” (ZM, 1951.).

U Zagrebu postoji nekoliko albanski udruga i organizacija, ${ }^{20}$ međutim, naši sugovornici nisu njihovi aktivni članovi. Kao razlog su naveli

\footnotetext{
${ }^{18}$ Ruski čaj jest naziv koji se na Kosovu koristi za indijski/crni čaj.

${ }^{19}$ Čaj iz rinfuze prelijeva se vrelom vodom u specijalnom čajniku. Pije se iz malih staklenih čašica.

${ }^{20}$ Prema Zakonu o udrugama Republike Hrvatske na stranicama Ureda za ljudska prava i prava nacionalnih manjina Vlade Republike Hrvatske registrirane su sljedeće udruge albanske nacionalne manjine u Zagrebu: Unija zajednica Albanaca u Republici Hrvatskoj,
} 
nedostatak vremena. Uglavnom ne posjećuju ni manjinska događanja, tek neki povremeno odlaze na važnija događanja, ${ }^{21}$ poput obilježavanja nacionalnih albanskih praznika - Dana zastave (Dan neovisnosti Albanije, 28. studenoga) i Dana neovisnosti Kosova (17. veljače). Dva kazivača bili su aktivni u albanskim udrugama samo tijekom rata na Kosovu (1998. 1999.) kada su prikupljali materijalnu i novčanu pomoć za sunarodnjake. Samo je jedan pekar član Zavičajne udruge "Hasi”. Osim kulturnopolitičkog karaktera, ta udruga ima i humani karakter, na način da financijski pomaže bolesnicima ili drugim potrebitima na Kosovu.

Kada promatramo razlike i sličnosti između dviju istraživanih grupa, vidimo da su one kod odabira bračnog druga te povezanosti s mjestom podrijetla velike. Riječ je o dvije grupe migranata čiji su pripadnici u Hrvatskoj već desetljećima, odnosno dvije generacije zlatara te suvremeni migranti - pekari. Podrijetlom su iz različitih dijelova Kosova, pekari iz ruralnog dijela kao što su i sami objasnili tradicionalne regije Hasi, a zlatari iz grada Prizrena. Osim toga, i različita religijska pripadnost uvjetuje velike razlike. S jedne strane, to su razlike u integraciji s domicilnim većinskim hrvatskim stanovništvom, no s druge se strane upućuje na nepovezanost etničkog i religijskog identiteta te potrebu propitivanja što je u ovom slučaju nacionalno. Naime, naši kazivači iz dviju istraživanih grupa nisu povezani bračno, prijateljski, ni na bilo koji drugi način. Dapače, zlatari su tijekom intervjua naglašavali sličnosti s Hrvatima upravo zbog iste vjerske pripadnosti.

\section{ZAKLJUČAK}

U Zagrebu živi oko 5000 građana albanskog podrijetla i bave se raznim zanimanjima, no kao što pokazuju podaci iz Udruženja obrtnika grada Zagreba, većina zagrebačkih pekarnica i zlatarnica u vlasništvo je albanskih

\footnotetext{
Albansko kulturno društvo u Hrvatskoj "Shkendija”, Klub albanskih žena "Kraljica Teuta", Forum albanskih intelektualaca u Hrvatskoj i Udruga albanskih žena u Zagrebu "Drita" (više vidjeti na: https://pravamanjina.gov.hr/nacionalne-manjine/nacionalnemanjine-u-republici-hrvatskoj/albanci/380). Osim ovih udruga, pretraživanjem pomoću tražilice Google pronalazimo i druge udruge, primjerice: Udruga Albanaca Kosova Zagreb, Udruga Albanaca branitelja $u$ hrvatskom Domovinskom ratu.

${ }^{21}$ Vijeće albanske nacionalne manjine Grada Zagreba također organizira brojna događanja (više vidjeti na: www.albanci-zagreb.hr).
} 
poduzetnika. Cilj je rada bio prikazati sličnosti i razlike između ove dvije grupe zanatlija, pekara podrijetlom iz ruralnih prostora regije Hasija na jugozapadu Kosova, te zlatara iz grada Prizrena. Dakako, razlike su uvjetovane i vremenom njihova dolaska, odnosno odluke o trajnom preseljenju.

Kod obje istraživane skupine kazivača prve su migracije Albanaca s Kosova bile sezonske migracije mladih muškaraca. Zlatari katolici s kojima smo razgovarale doselili su nekoliko desetljeća ranije ili su rođeni u Zagrebu. Dakle, sklapali su brakove s Hrvaticama, prije su se odlučili za stalno preseljenje u Hrvatsku, danas na Kosovu nemaju nekretnine, njihove su transnacionalne prakse manje, odnosno dobro su integrirani u hrvatsko društvo. Pekari muslimani pripadaju novijim valovima doseljenika, svi su rođeni na Kosovu i odabirali su supruge iz svoga rodnog kraja. Dok su oni radili u Hrvatskoj, one su živjele, a neke i danas žive, u tradicijskim oblicima mnogočlanih obitelji na Kosovu. Većina supruga preselila se u Zagreb nakon suprugove/obiteljske odluke o trajnom preseljenju. Unatoč formalnom preseljenju u Hrvatsku, što je povezano i s političkim kontekstom (raspadom Jugoslavije i osamostaljenjem Hrvatske i Kosova), ovi migranti zatražili su hrvatsko državljanstvo i postali pripadnici nacionalne manjine.

No unatoč ovoj pravnoj promjeni, pekari i njihove obitelji i danas prakticiraju, kako sami kažu, život na "oba mjesta". U jednom primjeru obitelj osam godina živi dislocirano. Pekari po nekoliko puta godišnje odlaze u rodna mjesta, ondje provode godišnje odmore, školuju djecu, pronalaze bračnog druga i organiziraju tradicijske svadbe te, kako to nalažu običajne norme ponašanja, financijski pomažu proširenu obitelj na Kosovu koja nije migrirala. Iako žive u Zagrebu, pekari muslimani nastoje zadržati "sve tradicije" svoga kraja.

Ono što karakterizira obje istraživane skupine jest etničko, tj. obiteljsko poduzetništvo. Oba se zanata više ili manje jednakim intenzitetom prenose s generacije na generaciju s time da se posljednjih godina zanati prenose na svu djecu koja to žele ili imaju afiniteta, neovisno o spolu. Mladi pripadnici istraživane etničke skupine stječu praksu unutar proširenih obitelji ili šire rodbinske zajednice. ${ }^{22}$ Ona im osigurava prvi posao, a kada se procijeni

${ }^{22}$ Tko je kod albanskih poduzetnika član šire rodbinske zajednice, ostaje temom drugog istraživanja. 
da mogu samostalno raditi, članovi im financijski pomažu otvoriti prvu radnju. Kao privatni poduzetnici, zauzvrat oni zapošljavaju mlađe članove, te će im jednog dana pomoći pri otvaranju njihovih radnji, kako se to već generacijama prakticira. Ovu etničku solidarnost i financijsku ispomoć, osim našeg istraživanja, pokazuju i istraživanja drugih autora koji su istraživali Albance u Švicarskoj i Sloveniji. Ovakve tradicijsko - običajne prakse rezultiraju da mladi ljudi već u dvadesetim godinama života postaju privatni poduzetnici, ali i da sami odlučuju do kada će aktivno raditi. Naši kazivači zlatari rade "do kada sami procjene da žele/mogu" iako prema hrvatskim zakonima svi imaju uvjete za odlazak u mirovinu.

Pripadnici obiju skupina imigranata imali su prije dolaska u Zagreb i druga migracijska iskustva, od čega zlatari uglavnom na jadranskoj obali. Osim činjenice da je Zagreb glavni grad te da ima veliko tržište, privlačan faktor preseljenja bili su prijašnji migranti, odnosno migrantske mreže. Kazivanja pokazuju da zlatarske obitelji i danas prakticiraju tradicijske sezonske migracije u turističkoj sezoni na Jadranu, no s promijenjenom adresom stalnog boravka - sada je Kosovo zamijenio Zagreb.

Najviše razlika pokazalo se u privatnim životima zanatlija. U pekarskim obiteljima govori se albanskim jezikom, za razliku od zlatarskih u kojima se većinom govori hrvatskim. Prilikom strukovnih i etnički okupljanja obje grupe govore uglavnom albanskim jezikom. U svim obiteljima prilikom važnijih životnih i godišnjih običaja priprema se albanska hrana, sluša se albanska muzika itd. Možemo reći da je riječ o homogenim etničkim i strukovnim zajednicama, posebice pekarima islamske vjeroispovijesti. Nitko od kazivača koji u Hrvatskoj trajno žive ne planira se vratiti na Kosovo. 


\section{LITERATURA}

ABU-LUGHOD, Lila. 1991. "Writing Against Culture”. U Recapturing Anthropology. Working in the Present, ur. R. G. Fox. New York: School of American Research Press, 137-163.

BABIĆ, Dragutin, ŠKILJAN, Filip i Drago ŽUPARIĆ-ILJIĆ. 2011. "Fokus grupe Analiza provedenog istraživanja / Albanci”. U Dragutin BABIĆ et al. Nacionalne manjine u Zagrebu. Zagreb: Plejada, 263-269.

BARDHOSHI, Nebi. 2004. "Veçori të ndarjes së pronës në krahinën e Hasit". U Kultura popullore. Tiranë: Akademia e Shkencave e Shqipërisë, Instituti i kulturës popullore, 99-127.

BAUER, Thomas i Klaus ZIMMERMANN. 1995. "Modelling International Migration: Economic and Econometric issues". U Causes of International Migration. Proceedings of a workshop, Eurostat, Luxembourg, 14-16 December 1994, Luxembourg, 95-115.

BRETTELL, Caroline. 2003. Anthropology and Migration. Essays on Transnationalism, Ethnicity and Identity. Walnut Creek, Calif.: Altamira Press.

CASTLES, Stephen i Mark J. MILLER. 2003. The age of Migration. London: Palgrave Macmillan.

ČAPO ŽMEGAČ, Jasna. 2003. "Dva lokaliteta, dvije države, dva doma: transmigracija hrvatskih ekonomskih migranata u Münchenu". Narodna umjetnost, vol. 40/2:117131. https://hrcak.srce.hr/27796

DAHINDEN, Janine. 2005. "Contesting transnationalism? Lessons from the study of Albanian migration networks from former Yugoslavia". Global networks. A Journal of transnational affairs, vol. 5/2:191-208. https://doi.org/ 10.1111/j.14710374.2005.00114.x

DOTA, Franko 2010. Zaraćeno poraće. Konfliktni i konkurentski narativi o stradanju $i$ iseljavanju Talijana Istre. Zagreb: Srednja Europa.

DRISHTI, Riza. 1976. "Punimi i armëve të zjarrit nga shqiptarët në shekujt XVII-XIX". U Konferenca kombëtare e studimeve etnografike: 28-30 qershor 1976. Tiranë: Akademia e Shkencave e RPSH, Instituti i Historisë, Sektori i Etnografisë, 357-370.

ENDERSEN, Cecilie. 2012. Is the Albanian's religion really "Albanianism"?: Religion and nation according to Muslim and Christian leaders in Albania. Wiesbaden: Harrassowitz Verlag.

FAIST, Thomas, FAUSER, Margit i Eveline REISENAUER. 2013. Transnational migration. Cambridge: Polity.

GLICK SCHILLER, Nina, Linda BASCH i Cristina BLANC-SZANTON, ur. 1992. Towards a Transnational Perspective on Migration: Race, Class, Ethnicity and Nationalism Reconsidered. New York: New York Academy of Sciences. 
GLICK SCHILLER, Nina i Ayse ÇAGLAR. 2009. “Towards a Comparative Theory of Locality in Migration Studies: Migrant Incorporation and City Scale”. Journal of Ethnic and Migration Studies, vol. 35/2:177-202. https://doi. org/10.1080/13691830802586179

GREGORIČ BON, Nataša. 2016. "Rooting Routes: (Non-)Movements in Southern Albania". U Moving Places: Relations, Return and Belonging, ur. Nataša Gregorič Bon i Jaka Repič. New York - Oxford: Berghahn, 63-84.

HEIGL, Franziska, KINEBANIAN, Astrid i Staffan JOSEPHSSON. 2011. "I think of my family, therefore I am: Perceptions of daily occupations of some Albanians in Switzerland”. Scandinavian Journal od Occupational Therapy, vol. 18/1:36-48. doi.org/10.3109/11038120903552648

HOTI, Avdullah. 2005. "Human Capital and Unemployment in Transition Economies: The case of Kosova". U 65th Anniversary Conference of the Institute of Economics, Zagreb, November 18-19, 2004: Proceedings. Zagreb: The Institute of Economics, 163-188. http://www.eizg.hr/Download.ashx?FileID=ac92ddae-b6f0-4e13-ba45705c383930be (pristup 10. 3. 2017.).

ISENI, Bashkim. 2013. "Albanian-speaking transnational populations in Switzerland: continuities and shifts". Southeast European and Black Sea Studies, vol. 13/2:227243. https://doi.org/10.1080/14683857.2013.802174

KADRIU, Lumnije. 2013. "Konceptet kohë e hapësirë dhe pushimet e praktikuara nga diaspora". Gjurmime Albanologjike - Folklor dhe Etnologji, vol. 43:305-316.

KING, Russell i Julie VULLNETARI. 2009. "Remittances, return, diaspora: framing the debate in the context of Albania and Kosova". Southeast European and Black Sea Studies, vol. 9/4:385-406. https://doi.org/10.1080/14683850903314907

KLVANOVA, Radka. 2010. "Moving Through Social Networks: The Case of Armenian Migrants in the Czech Republic". International Migration, vol. 48/2:103-132. https://doi.org/10.1111/j.1468-2435.2009.00565.x

KUTI, Simona i Saša BOŽIĆ. 2016. Transnacionalni socijalni prostori: migrantske veze preko granica Hrvatske. Zagreb: Naklada Jesenski i Turk, Hrvatsko sociološko društvo.

LENTIĆ, Ivo. 1984. Dubrovački zlatari 1600.-1900. Zagreb: Društvo povjesničara umjetnosti Hrvatske.

LEŠDEDAJ, Agron, NIKOLIĆ ĐERIĆ, Tamara i Ivona ORLIĆ. 2015. Filigran: srebrna nit od Kosova do Istre. Pazin: Etnografski muzej Istre.

LEVITT, Peggy i Nina GLICK SCHILLER. 2004. "Conceptualizing Simultaneity: A Transnational Social Field Perspective on Society". International Migration Review, vol. 38/3:1002-1039. https://doi.org/10.1111/j.1747-7379.2004.tb00227.x

MITRUSHI, Llambrini. 1977. "Zhvillimi i mjeshtërisë së argjendarisë në Shqipëri”. U Konferenca kombëtare e studimeve etnografike: 28-30 qershor 1976. Tiranë: Akademia e Shkencave e RPSH, Instituti i Historisë, Sektori i Etnografisë, 371-381. 
MÜGGE, Liza. 2016. "Transnationalism as a Research Paradigm and Its Relevance for Integration". U Integration Processes and Policies in Europe: Contexts, Levels and Actors, ur. Blanca Garcés-Mascareñas i Rinus Penninx. Cham: Springer, 109-127. http://link.springer.com/book/10.1007\%2F978-3-319-21674-4 (pristup 12. 10. 2016.).

PACA, Dafina. 2015. “'Schatzi': Making Meaning of Diaspora”. JOMEC Journal, vol. 7:1-17. https://publications.cardiffuniversitypreš.org/index.php/JOMEC/article/ view/210 (pristup 14. 3. 2017.).

PENNINX, Rinus i Blanca GARCÉS-MASCAREÑAS. 2016. "The Concept of Integration as an Analytical Tool and as a Policy Concept". U Integration Processes and Policies in Europe: Contexts, Levels and Actors, ur. Blanca Garcés-Mascareñas i Rinus Penninx. Cham: Springer, 11-30. http://link.springer.com/book/10.1007\% 2F978-3-319-21674-4 (pristup 12. 10. 2016.).

PERIČIĆ, Šime. 1993. Pregled gospodarstva Arbanasa u prošlosti. Zadar: Mjesna zajednica Arbanasi.

PERIĆ KASELJ, Marina, ŠKILJAN, Filip i Aleksandar VUKIĆ. 2015. "Događaji i etnička situacija: promjene identiteta nacionalnih manjinskih zajednica u Republici Hrvatskoj”. Studia ethnologica Croatica, vol. 27:7-70. https://doi.org/10.17234/ SEC.27.1

SHKODRA, Zija. 1977. "Zejet popullore qytetare gjatë shekujve XVII-XIX”. U Konferenca kombëtare e studimeve etnografike: 28-30 qershor 1976. Tiranë: Akademia e Shkencave e RPSH, Instituti i Historisë, Sektori i Etnografisë, 349-355.

STIPČEVIĆ, Aleksandar. 2011. Tradicijska kultura zadarskih Arbanasa. Zagreb: Ibis grafika.

ŠTIKS, Igor. 2006. "Nationality and Citizenship in the Former Yugoslavia: From Disintegration to European Integration". Southeast European and Black Sea Studies, vol. 6/4:483-500. https://doi.org/10.1080/14683850601016366

TIRTA, Mark. 2013. "Hasi në traditë, popullimi, migrimet”. U: Lëvizje migruese të shqiptarëve të brendshme e në popujt më afër. Tiranë: Akademia e shkencave, 265-335.

VADNJAL, Jaka. 2014. "The importance of social capital within an ethnic community: Albanian entrepreneurs in Slovenia". Dve domovini / Two Homelands, vol. 40:123137. https://www.dlib.si/details/URN:NBN:SI:DOC-WDTIG7XR

VATHI, Zanai i Richard BLACK. 2007. "Migration and Poverty Reduction in Kosovo". U Development Research Centre on Migration, Globalisation and Poverty. Brighton: University of Sussex, Development Research Centre on Migration, Globalisation and Poverty. http://www.migrationdrc.org/publications/working_papers/WP-C12. pdf (pristup 14. 3. 2017.).

XHEMILI, Bekim. 2016. "Filigrani dhe Muzeu - zeje, art, komunikim". Gjurmime Albanologjike - Folklor dhe Etnologji, vol. 46:215-228. 


\section{INTERNETSKI IZVORI}

Acta et diplomata res Albaniae mediae aetatis illustrantia. Vol. II, Annos 1344-1406 continens. 1918. Collegerunt et digesserunt Dr. Ludovicus de Thallóczy, Dr. Constantinus Jireček et Dr. Emilianus de Sufflay. Vindobonae: A. Holzhausen. http://gallica.bnf.fr/ark:/12148/bpt6k5626777t (pristup 22. 3. 2017.).

Ministarstvo vanjskih i europskih poslova RH. crovisa.mvep.hr (pristup 22. 3. 2017.).

Popis stanovništva 1981. Zagreb: Državni zavod za statistiku. www.dzs.hr (pristup 12. 10. 2016.).

Popis stanovništva 1991. Zagreb: Državni zavod za statistiku. www.dzs.hr (pristup 12. 10. 2016.).

Popis stanovništva 2001. Zagreb: Državni zavod za statistiku. www.dzs.hr (pristup 12. 10. 2016.).

Popis stanovništva 2011. Zagreb: Državni zavod za statistiku. www.dzs.hr (pristup 12. 10. 2016.).

Udruženje obrtnika grada Zagreba. www.obrtnici-zagreb.hr/ (pristup 22. 3. 2017.).

Veleposlanstvo RH u Prištini. ks.mvep.hr (pristup 22. 3. 2017.).

Vijeće albanske nacionalne manjine Grada Zagreba. www.albanci-zagreb.hr (pristup 22. 3. 2017.).

Vlada RH, Ured za ljudska prava i prava nacionalnih manjina - Albanci. https:// pravamanjina.gov.hr/nacionalne-manjine/nacionalne-manjine-u-republicihrvatskoj/albanci/380 (pristup 22. 3. 2017.).

\section{KONZULTIRANI ZAKONI}

Ustav Republike Hrvatske. Narodne novine (NN) 56/90, http://narodne-novine.nn.hr/ clanci/sluzbeni/1990_12_56_1092.html (pristup 22. 3. 2017.).

Ustavni zakon o ljudskim pravima i slobodama $i$ o pravima etničkih $i$ nacionalnih zajednica ili manjina u Republici Hrvatskoj. Narodne novine (NN) 65/91, 27/92, 34/92, http://narodne-novine.nn.hr/clanci/sluzbeni/1992_06_34_896.html (pristup 22. 3. 2017.).

Zakon o hrvatskom državljanstvu. Narodne novine (NN) 53/91, 70/91, 28/92, 113/93 Odluka USRH, 4/94 - Odluka USRH, 130/11 i 110/2015. 
Marijeta Rajković Iveta

Rina Geci

\section{ARTARËT DHE FURRTARËT SHQIPTARË NGA KOSOVA NË ZAGREB: MIGRIMET DHE SIPËRMARRJA ETNIKE}

Punimi është i bazuar në intervista kualitative me shqiptarë nga Kosova, artarë (katolikë nga Prizreni) dhe furrtarë (myslimanë nga rajoni i Hasit), të cilët jetojnë në Zagreb. Informatorët dhe paraardhësit e tyre janë migrantë ekonomikë, të cilët gjatë bashkëjetesës në Jugosllavi kanë ardhur në territorin e Republikës së Kroacisë për të punuar, kryesisht në vendet turistike të bregdetit adriatik. Shumica e migrimeve sezonale të meshkujve janë shndërruar në shpërngulje të përhershme në qytetin e Zagrebit, ndërsa me shpërbërjen e Jugosllavisë, këta migrantë janë bërë pjesëtarë të minoritetit kombëtar në Republikën e Kroacisë. Duke përdorur etnografinë personale, bazuar në teoritë e sistemeve të migrimeve, teoritë e integrimit social e kulturor dhe teorinë e transnacionalizmit, qëllimi i punimit ka qenë hulumtimi i përvojave të jetuara të migrantëve. Përveç paraqitjes së shkaqeve të migrimeve dhe rimigrimeve, arsyeve dhe intensitetit të (jo)shndërrimit të migrimeve sezonale në ato të përhershme, qëllimi i punimit ka qenë që të hulumtohet edhe mësimi i zanateve dhe sipërmarrja etnike. Sot, shumica e furrave dhe artarive në Zagreb janë në pronësi të sipërmarrësve shqiptarë. Të dyja zanatet përcillen te pasardhësit. Familja e gjerë dhe/ose rrethi i gjerë i kushërinjve ua siguron punën, pastaj iu ndihmon financiarisht të hapin punëtorinë, ku ata punësojnë gjeneratat e ardhshme e kështu përsëri. Artarët katolikë janë të lindur ose me dekada jetojnë në Zagreb, martohen me kroate, në Kosovë nuk kanë prona, praktikat e tyre transnacionale janë të vogla dhe mirë janë të integruar në shoqërinë kroate. Furrtarët myslimanë u takojnë valëve më të reja të të shpërngulurve, të gjithë janë të lindur në Kosovë, kanë zgjedhur bashkëshortë nga vendi i origjinës dhe ngushtë janë të lidhur me vendlindjen. Dallimet më të mëdha vërehen në jetët private të zanatlive.

Fjalë kyç: Shqiptarët nga Kosova, Zagreb, furrtarët, artarët, migrime sezonale, pakic kombëtare

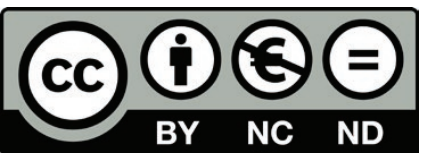

Articles published in this journal are Open Access and can be distributed under the terms and conditions of the Creative Commons license Attribution-NonCommercial-NoDerivatives 4.0 (http://creativecommons.org/licenses/by-nc-nd/4.0/) 